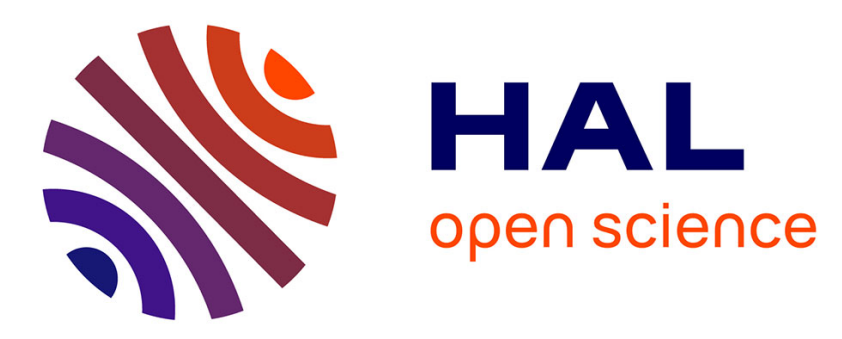

\title{
New transience bounds for long walks in weighted digraphs
}

\author{
Bernadette Charron-Bost, Matthias Függer, Thomas Nowak
}

\section{To cite this version:}

Bernadette Charron-Bost, Matthias Függer, Thomas Nowak. New transience bounds for long walks in weighted digraphs. Eurocomb 2013, Sep 2013, Pise, Italy. pp.623-624, 10.1007/978-88-7642-4755_103. hal-00993814

\section{HAL Id: hal-00993814 https://hal.science/hal-00993814}

Submitted on 21 May 2014

HAL is a multi-disciplinary open access archive for the deposit and dissemination of scientific research documents, whether they are published or not. The documents may come from teaching and research institutions in France or abroad, or from public or private research centers.
L'archive ouverte pluridisciplinaire HAL, est destinée au dépôt et à la diffusion de documents scientifiques de niveau recherche, publiés ou non, émanant des établissements d'enseignement et de recherche français ou étrangers, des laboratoires publics ou privés. 


\title{
NEW TRANSIENCE BOUNDS FOR LONG WALKS IN WEIGHTED DIGRAPHS
}

\author{
BERNADETTE CHARRON-BOST ${ }^{1,2}$, MATTHIAS FÜGGER ${ }^{3}$, AND THOMAS NOWAK ${ }^{2}$
}

Fix two nodes $i$ and $j$ in an edge-weighted diagraph and form the following sequence: Let $a(n)$ be the maximum weight of walks from $i$ to $j$ of length $n$; if no such walk exists, $a(n)=-\infty$. It is known that, if $G$ is strongly connected, the sequence $a(n)$ is always eventually periodic with linear defect, i.e., after the transient, $a(n+p)=a(n)+p \cdot \lambda$. In fact, the ratio $\lambda$ is the largest mean weight of cycles in $G$. We call these cycles critical. Periodicity stems from the fact that the weights of critical cycles eventually dominate the maximum weight walks.

In this paper, we show two new asymptotically tight upper bounds on transients in weighted digraphs, taking into account the graph parameters cyclicity and girth. The previously best bound of Hartmann and Arguelles (Math. Oper. Res. 24, 1999) is, in general, incomparable with both our bounds. The significant benefit of our two new bounds is that each of them turns out to be linear in the number of nodes in various classes of weighted digraphs, whereas Hartmann and Arguelles' bound is intrinsically at least quadratic. In particular, our bounds are linear for (bi-directional) trees.

We hence prove the following two upper bounds on the transient in strongly connected digraphs with $N$ nodes. They both contain the (unweighted) index of convergence $\operatorname{ind}(G)$, i.e., the transient of $G$ when choosing all weights to be equal. The term $\|G\|$ denotes the difference of the maximum and minimum weight of edges in $G$. The mean weight of critical cycles is denoted by $\lambda$, and $\lambda_{\mathrm{nc}}$ denotes the largest mean weight of cycles that have no node on critical cycles. Denote by $G_{c}$ the subgraph induced by the critical cycles.

Theorem 1 (Repetitive Bound). Denoting by $\hat{g}$ the maximum girth of strongly connected components of $G_{c}$, the transient between any two nodes is at most

$$
\max \left\{\frac{\|G\| \cdot(3 N-2+\operatorname{ind}(G))}{\lambda-\lambda_{\mathrm{nc}}},(\hat{g}-1)+2 \hat{g} \cdot(N-1)\right\} .
$$

Theorem 2 (Explorative Bound). Denoting by $\hat{\gamma}$ and ind the maximum cyclicity and maximum index of strongly connected components of $G_{c}$, respectively, the transient between any two nodes is at most

$$
\max \left\{\frac{\|G\| \cdot(3 N-2+\operatorname{ind}(G))}{\lambda-\lambda_{\mathrm{nc}}},(\hat{\gamma}-1)+2 \hat{\gamma} \cdot(N-1)+\mathrm{ind}\right\} .
$$

\footnotetext{
${ }^{1}$ CNRS. ${ }^{2}$ École polytechnique. ${ }^{3}$ TU Wien. The full paper is arXiv:1209.3342 [cs.DM] .
} 